\title{
Ganglioside GD1a promotes oocyte maturation, furthers preimplantation development, and increases blastocyst quality in pigs
}

\section{Jin-Woo KIM ${ }^{1)}$, Hyo-Jin PARK ${ }^{1)}$, Sung-Kyu CHAE ${ }^{1)}$, Jae-Hyun AHN ${ }^{1)}$, Geon-Yeop DO'1), Young-Kug $\mathrm{CHOO}^{2)}$, Joung Jun PARK ${ }^{3)}$, Bae Dong JUNG ${ }^{4)}$, Sun-Uk $\mathrm{KIM}^{5)}$, Kyu-Tae CHANG ${ }^{5}$ ) and Deog-Bon KOO'1)}

\author{
1) Department of Biotechnology, College of Engineering, Daegu University, Gyeongbuk 712-714, Republic of Korea \\ ${ }^{2)}$ Department of Biological Science, College of Natural Sciences, Wonkwang University, Jeonbuk 570-749, Republic of \\ Korea \\ 3) Animal Reproduction \& Biotechnology Center, Myung-Poom Hanwoo Consulting, Gangwon 225-807, Republic of Korea \\ 4) College of Veterinary Medicine \& Institute of Veterinary Science, Kangwon National University, Chuncheon 200-701, \\ Republic of Korea \\ 5) National Primate Research Center, Korea Research Institute of Bioscience and Biotechnology, Chungbuk 363-883, \\ Republic of Korea
}

\begin{abstract}
Gangliosides are key lipid molecules required for the regulation of cellular processes such as proliferation, differentiation, and cell signaling, including signaling of epidermal growth factor receptor (EGFR). Epidermal growth factor (EGF) has long been considered a potential regulator of meiotic and cytoplasmic maturation in mammalian oocytes. However, there is no report on the direct effect of ganglioside GD1a in porcine oocyte maturation. In this study, we first investigated a functional link between GD1a and meiotic maturation during in vitro maturation (IVM) of porcine embryos. Moreover, we confirmed the effect of exogenous GD1a treatment on blastocyst development, quality, and fertilization rate in early embryonic development. First, we observed that the protein level of ST3GAL2, a GD1a synthesizing enzyme, significantly increased $(\mathrm{P}<0.01)$ in cumulus-oocyte-complexes $(\mathrm{COCs})$ during IVM progress. The proportion of arrested germinal vesicles $(\mathrm{GV})$ increased in oocytes treated with EGF+GD1a $(41.6 \pm 1.5 \%)$ at the IVM I stage. Upon completion of meiotic maturation, the proportion of metaphase II (M II) was significantly higher $(\mathrm{P}<0.05)$ in the EGF+GD1a $(89.9 \pm 3.6 \%)$ treated group. After IVF, the percentage of penetrated oocytes was significantly higher $(\mathrm{P}<0.05)$ in the EGF+GD1a $(89.1 \pm 2.3 \%)$ treated group than in the control group. Furthermore, exogenous GD1a treatment improved the developmental competence and quality of blastocysts during preimplantation embryo development stage. These results suggest that ganglioside GD1a may play an important role in IVM mechanisms of porcine maturation capacity. Furthermore, our findings will be helpful for better promoting the embryo development and blastocyst quality in pigs.
\end{abstract}

Key words: Ganglioside GD1a, Meiotic maturation, Preimplantation development, Pigs

(J. Reprod. Dev. 62: 249-255, 2016)

G ycosphingolipids can be divided into neutral glycosphingolipids and acidic glycosphingolipids. Acidic glycosphingolipids containing one or more negatively charged sialic acid residues in their carbohydrate moiety are referred to as gangliosides [1]. Recently, gangliosides have been found to be highly important in immunology, cancer mechanisms, embryo development, and receptor signaling pathways. Gangliosides are highly abundant in neural cells, and it has been suggested that they play important roles in various processes such as cell differentiation, growth control, and signaling [2]. Most gangliosides have also been shown to regulate the activity

Received: June 24, 2015

Accepted: January 21, 2016

Published online in J-STAGE: February 9, 2016

(C)2016 by the Society for Reproduction and Development

Correspondences: D-B Koo (e-mail: dbkoo@daegu.ac.kr) and K-T Chang (e-mail: changkt@kribb.re.kr)

This is an open-access article distributed under the terms of the Creative Commons Attribution Non-Commercial No Derivatives (by-nc-nd) License $<$ http://creativecommons.org/licenses/by-nc-nd/4.0/>. of epidermal growth factor receptor (EGFR), platelet-derived growth factor receptor (PDGFR), and fibroblast growth factor receptor (FGFR) [3, 4]. Notably, ganglioside-mediated receptor activation can be altered by inflammation, cancer, and neuronal cells.

EGFR belongs to a family of receptor tyrosine kinases. Activation of EGFR affects various signaling pathways related to cell proliferation and apoptosis resistance [5]. Moreover, the EGFR signaling pathway plays an important role in vertebrate oocytes, where it regulates specification and survival [6]. EGFR activation by EGF or EGF-like factors is known to induce resumption of meiosis in oocytes and cumulus cell expansion in pigs [7, 8], rats [9], mice [10], humans [11], and cattle [12].

The EGFR regulates oocyte maturation; expression of EGFR plays an important role in both cumulus cells and oocytes [13]. Maturation refers to the meiotic maturation of oocytes up until metaphase II (IVM II; $44 \mathrm{~h}$ ) which is required for ovulation and fertilization. During oocyte maturation until IVM II phase, secreted EGF signals in a paracrine manner through the EGFR to stimulate cumulus cell expansion of cumulus-oocyte complexes (COCs). Therefore, changes 
in EGFR and EGF secretion from COCs regulate oocyte meiotic maturation during in vitro maturation (IVM) [14].

Ganglioside GD1a is specifically formed by the addition of sialic acid to ganglioside GM1a by the synthesizing enzyme ST3 $\beta$-galactoside $\alpha$-2, 3 -sialyltransferase 2 (ST3GAL2) [15]. GD1a promotes proliferation of normal human dermal fibroblasts and differentiation of osteoblasts by activating EGFR signaling pathways $[3,16]$. Moreover, GDla as membrane component is also important in cellular signaling pathways required for oocyte maturation. According to a recent study, GD1a has been found to be expressed in interstitial cells during ovarian maturation in mice [17]. Moreover, exogenous GD1a treatment enhances EGFR activation and ligand binding [16]. However, there has been no investigation to date on the direct role and effects of GD1a expression in oocyte meiotic maturation during in vitro maturation of porcine oocytes and COCs.

Regulation of ganglioside GD1a may play a fundamental role in oocyte maturation similar to the role of EGF in cumulus cells of COCs. Therefore, we designed present studies to determine whether the addition of ganglioside GD1a into maturation medium might regulate oocyte maturation until IVM II like EGF. In addition, the effect of exogenous GD1a on matured oocyte was investigated by measuring fertilization rate and subsequent embryonic development parameters. Furthermore, the present study was initiated to suggest a functional link between ganglioside GD1a and oocyte maturation in porcine oocytes during IVM progression.

\section{Materials and Methods}

\section{Chemicals reagents}

Unless otherwise stated, all chemicals reagents used in this study were purchased from Sigma Chemical (St. Louis, MO, USA).

\section{In vitro maturation (IVM)}

Porcine ovaries were obtained from non-pregnant sows at a local abattoir and were transported to the laboratory in $0.9 \%$ saline supplemented with $75 \mu \mathrm{g} / \mathrm{ml}$ potassium penicillin $\mathrm{G}$ at approximately $30-35^{\circ} \mathrm{C}$. Immature cumulus-oocyte complexes (COCs) were then aspirated from 3- to 6-mm follicles using a disposable 10-ml syringe with an 18-gauge needle. [18]. Undamaged COCs with similar quality cytoplasm and the surrounding cumulus cells were collected by mouth pipetting, then washed three times in Tyrode's lactate-N2-hydroxyethylpiperazine-N'-2-ethanesulfonic acid (TL-HEPES) medium. Next, 50-60 immature COCs were matured in $500 \mu \mathrm{l}$ of in vitro maturation medium in a four-well multidish (Nunc, Roskilde, Denmark) at $38.5^{\circ} \mathrm{C}$ under $5 \% \mathrm{CO}_{2}(\mathrm{v} / \mathrm{v})$. BSA-free North Carolina State University (NCSU)-23 medium supplemented with $10 \%$ follicular fluid (v/v), $0.57 \mathrm{mM}$ cysteine, $10 \mathrm{ng} / \mathrm{ml} \beta$-mercaptoethanol, 10 $\mathrm{ng} / \mathrm{ml}$ EGF, $10 \mathrm{IU} / \mathrm{ml}$ pregnant mare's serum gonadotropin (PMSG) and $10 \mathrm{IU} / \mathrm{ml}$ human chorionic gonadotropin (hCG) was used for oocyte maturation [19]. After culturing for $22 \mathrm{~h}, \mathrm{COCs}$ were washed three times and then further cultured in PMSG and hCG-free maturation medium for $22 \mathrm{~h}$. During the maturation periods, GDla was added to the maturation medium when appropriate. Upon completion of IVM, the oocytes were subjected to in vitro fertilization.

\section{In vitro fertilization (IVF) and culture (IVC)}

In vitro fertilization of porcine oocytes was performed as described by Abeydeera and Day [20]. The IVF medium, modified Tris-buffered medium (mTBM), consisted of $113.1 \mathrm{mM} \mathrm{NaCl}, 3 \mathrm{mM} \mathrm{KCl}, 7.5$ $\mathrm{mM} \mathrm{CaCl} 2,5 \mathrm{mM}$ sodium pyruvate, $11 \mathrm{mM}$ glucose, $20 \mathrm{mM}$ Tris, $2.5 \mathrm{mM}$ caffeine sodium benzoate and $1 \mathrm{mg} / \mathrm{ml}$ BSA. Fresh semen was kindly supplied once a week by AI (Darby Porcine AI Center, Anseong, Korea) and kept at $17^{\circ} \mathrm{C}$ for 5 days. Semen was washed three times by centrifugation in PBS supplemented with $1 \mathrm{mg} / \mathrm{ml} \mathrm{BSA}$ (w/v), $100 \mathrm{mg} / \mathrm{ml}$ penicillin $\mathrm{G}$, and $75 \mathrm{mg} / \mathrm{ml}$ streptomycin sulfate. At the end of the washing period, spermatozoa were resuspended in $\mathrm{mTBM}$ at $\mathrm{pH}$ 7.8. Oocytes were subsequently washed three times in mTBM, and then placed into $48 \mu \mathrm{l}$ of mTBM under mineral oil. Next, $2 \mu \mathrm{l}$ of diluted spermatozoa were added to a $48 \mu \mathrm{l}$ drop of medium containing 15-20 oocytes to give a final concentration of $1.5 \times 10^{5}$ sperm $/ \mathrm{ml}$. Finally, oocytes were co-incubated with spermatozoa for $6 \mathrm{~h}$ at $38.5^{\circ} \mathrm{C}$ under $5 \% \mathrm{CO}_{2}$. Next, embryos were cultured in $50 \mu \mathrm{l}$ drops of PZM- 3 medium with $3 \mathrm{mg} / \mathrm{ml} \mathrm{BSA}$ at $38.5^{\circ} \mathrm{C}$ under $5 \%$ $\mathrm{CO}_{2}$. After $48 \mathrm{~h}$ of culture, 25-30 cleaved embryos were further cultured in $50 \mu \mathrm{l}$ drops of PZM-3 medium supplemented with $3 \mathrm{mg} /$ $\mathrm{ml} \mathrm{BSA}$ at $38.5^{\circ} \mathrm{C}$ under $5 \% \mathrm{CO}_{2}$ for 4 days. Blastocyst formation was evaluated after 6 day of culture.

\section{Assessment of meiotic maturation and pronucleus formation}

At the end of each IVM and IVF experiment, a representative sample was denuded by gently pipetting in $0.1 \%$ hyaluronidase $(\mathrm{w} / \mathrm{v})$ and then washing in PBS containing $0.1 \%$ polyvinyl alcohol $(\mathrm{PVA}, \mathrm{w} / \mathrm{v})$. Each sample were mounted on microscope slides. The samples were then fixed for 3 days in acetic acid:ethanol $(1: 3, \mathrm{v} / \mathrm{v})$ solution and stained with $0.1 \%$ acetic orcein $(\mathrm{v} / \mathrm{v})$ solution for 5 $\min$. The samples were de-stained in glycerol:acetic acid:water $(1: 1: 3, \mathrm{v} / \mathrm{v} / \mathrm{v})$ solution, after which the meiotic stage was evaluated microscopically (Leica, Solms, Germany).

\section{Western blot analysis}

Matured oocyte (30-40 DOs per group) and COC (25-30 COCs per group) lysates were prepared in PRO-PREP protein lysis buffer (iNtRON, Daejeon, Korea). Sample lysates were separated on a 10\% polyacrylamide gel by sodium dodecyl sulfate polyacrylamide gel electrophoresis (SDS-PAGE; Hoefer, Holliston, MA, USA) and then transferred to a nitrocellulose (NC) membrane (Pall Corporation, NY, USA). The membrane was blocked by incubation with $5 \%$ skim milk for $2 \mathrm{~h}$ at room temperature and then the membrane was incubated with the appropriate primary antibody; anti-ST3GAL2 or anti- $\beta$-actin (Santa Cruz Biotechnology, CA, USA). Membranes were washed with TBST buffer and then incubated with a secondary antibody-HRE-conjugated anti-mouse/rabbit IgG (Thermo Scientific, Rockford, IL, USA) for $2 \mathrm{~h}$ at room temperature. Next, the membranes were washed with TBST buffer. Antibody binding was detected using the Bight ${ }^{\mathrm{TM}}$ ECL Kit (Advansta, CA, USA) according to the manufacturer's instructions. Band intensities were quantified with Image J software (NIH, MD, USA). All experiments were performed at three times.

Assessment of apoptosis in blastocysts

Apoptotic blastocysts were detected using an In Situ Cell Death 
Detection Kit (Roche Diagnostics GmbH, Mannheim, Germany) according to the manufacturer's instructions. On day 6, the blastocysts from IVF were washed with $0.1 \%$ PVA in PBS and then fixed in $4 \%$ PFA in PBS for $1 \mathrm{~h}$ at room temperature. Next, blastocysts were permeablized using $0.1 \%(\mathrm{v} / \mathrm{v})$ Triton $\mathrm{X}-100$ for $30 \mathrm{~min}$ at $4{ }^{\circ} \mathrm{C}$. The fixed embryos were incubated in TUNEL reaction medium for $1 \mathrm{~h}$ at $38.5^{\circ} \mathrm{C}$, then washed and mounted on slides. Whole-mount embryos were examined under an epifluorescence microscope (Olympus, Tokyo, Japan) following TUNEL assay and DAPI staining, and the number of apoptotic nuclei and total number of nuclei were counted.

\section{Statistical analysis}

All percentage data obtained in this study are presented as the mean \pm standard deviation (SD). Moreover, Western blot experiments were performed in triplicate and all values were presented as the mean \pm standard error of the mean (SEM). The results were analyzed using either a one-way ANOVA followed by Bonferroni's Multiple Comparison Test or by performing a $t$-test. All data were analyzed using the GraphPad Prism 5.0 software package (San Diego, CA, USA). Differences were considered significant at $* \mathrm{P}<0.05, * *<$ 0.01 , and $* * *<0.001$.

\section{Results}

\section{GD1a synthesizing enzyme ST3GAL2 protein levels in DOs and COCs during IVM}

Many studies have reported that the expression of ganglioside GD1a can be accurately estimated by measuring the expression of its synthesizing enzyme ST3GAL2 [21, 22]. Therefore, we first measured the protein level of ST3GAL2 as a proxy for expression of GD1a in denuded oocytes (DOs) and cumulus cell oocytes (COCs) during the IVM process (IVM I; 22 h, IVM II; 44 h) by western blotting. As shown in Fig. 1, the expression of ST3GAL2 protein level was dramatically higher $(\mathrm{P}<0.05)$ in COCs of IVM II $(44 \mathrm{~h})$ than in COCs of IVM I (22 h). ST3GAL2 protein was only detected in COCs, and not in DOs. This result demonstrated that the GD1a synthesizing enzyme ST3GAL2 was only expressed in COCs of IVM II (44 h). Based on this result, we determined that COCs of IVM II ( $44 \mathrm{~h})$ could be used for the subsequent experiments using GD1a treatment.

\section{Effects of GD1a treatment during IVM on oocyte maturation}

First, to determine the proper concentration of GD1a treatment for COCs in IVM II, we evaluated aspects of oocyte maturation after treatment with various concentrations of GDla. Porcine oocytes were cultured with various concentrations $(1 \mu \mathrm{M}, 10 \mu \mathrm{M}$ and 20 $\mu \mathrm{M})$ of GD1a for $44 \mathrm{~h}$ in EGF-free medium. As shown in Fig. 2, the proportion of the metaphase II (M II) stage oocytes was significantly higher $(\mathrm{P}<0.05)$ in the $10 \mu \mathrm{M}$ GD1a treated group $(79.7 \pm 3.0 \%)$ than in the control $(57.2 \pm 1.3 \%)$.

Next, to confirm the effects of GD1a on oocyte maturation in vitro, we measured the meiotic maturation of porcine oocytes after exogenous GD1a treatment. Therefore, we investigated the proportion of meiotic maturation after GD1a and/or EGF treatment for M I or M II phase. As shown in Fig. 3, we confirmed that the number of oocytes that reached metaphase I (M I) was significantly higher $(\mathrm{P}<0.05)$ in
(A)

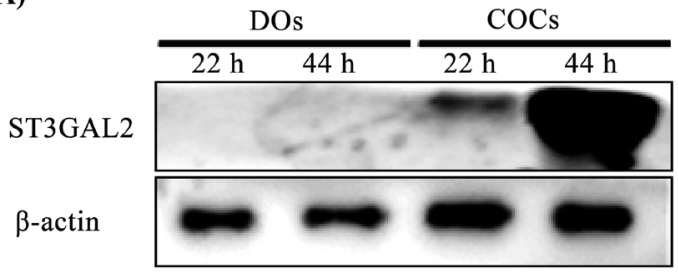

(B)

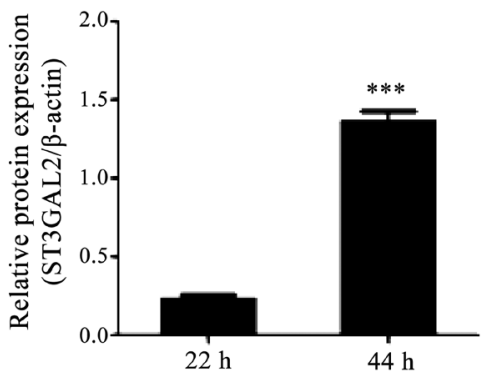

Fig. 1. Expression patterns of ST3GAL2 in DOs and COCs during in vitro maturation. (A) Protein levels of ST3GAL2 were examined in DOs and COCs during IVM I (22 h) and IVM II (44 h) by western blotting analysis. (B) Quantitative analysis of ST3GAL2 protein level in DOs and COCs during IVM I (22 h) and IVM II (44 h). Relative ST3GAL2 protein levels were normalized to $\beta$-actin as a control. Data in the bar graph represent the means \pm SEM of three independent experiments. Differences were considered significant at $* \mathrm{P}<0.05, * *<0.01$, and $* * *<0.001$.

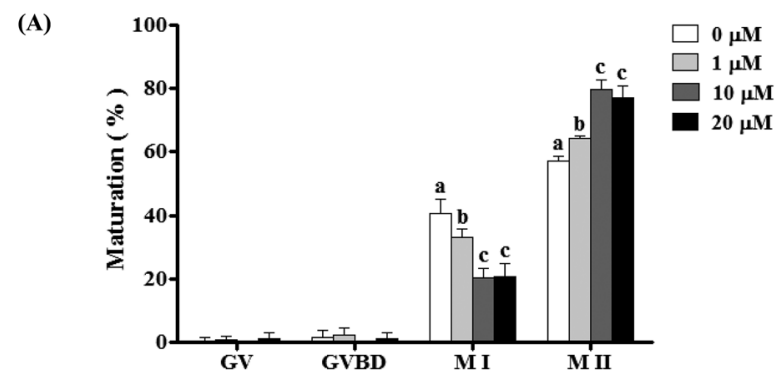

(B)

\begin{tabular}{cccccc}
\hline \multirow{2}{*}{$\begin{array}{c}\text { GDla } \\
(\mu \mathrm{M})\end{array}$} & $\begin{array}{c}\text { No. of } \\
\text { oocytes } \\
\text { examined }\end{array}$ & \multicolumn{5}{c}{ \% oocytes (n) } \\
\cline { 3 - 6 } & 164 & $0.5 \pm 0.9(1)$ & $1.7 \pm 1.8(3)$ & $40.6 \pm 3.9(66)^{\mathrm{d}}$ & $57.2 \pm 1.3(94)^{\mathrm{A}}$ \\
\hline 0 & 131 & $0.6 \pm 1.1(1)$ & $2.2 \pm 2.2(3)$ & $33.1 \pm 2.3(43)^{\mathrm{b}}$ & $64.2 \pm 0.8(84)^{\mathrm{b}}$ \\
\hline 1 & 129 & - & - & $20.3 \pm 3.0(26)^{\mathrm{c}}$ & $79.7 \pm 3.0(103)^{\mathrm{c}}$ \\
\hline 10 & 192 & $1.0 \pm 2.0(2)$ & $1.0 \pm 2.0(2)$ & $20.9 \pm 4.0(40)^{c}$ & $77.2 \pm 3.0(148)^{c}$ \\
\hline 20 & 192
\end{tabular}

Fig. 2. Effect of GD1a treatment on meiotic maturation of porcine oocytes. Nuclei were classified into GV, GVBD, M I, or M II stages. (A) Diagram of oocyte maturation. (B) Summary of meiotic maturation after IVM II, with or without GD1a treatment. This experiment was replicated at three times. Data are expressed as the means $\pm \mathrm{SD}$. Different superscript letters denote significant differences $(\mathrm{P}<0.05)$ 
(A)

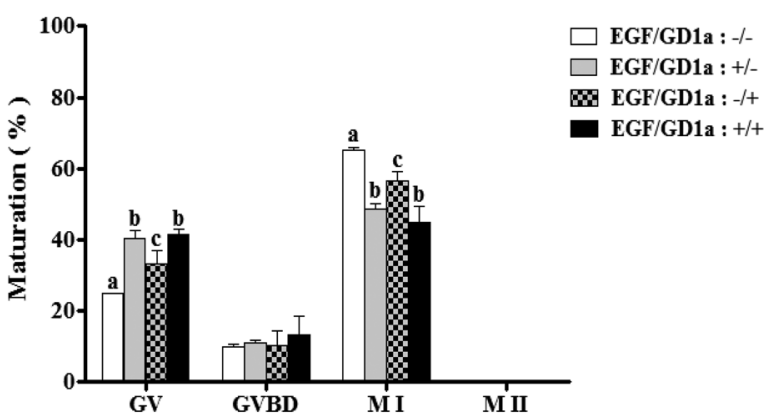

(B)

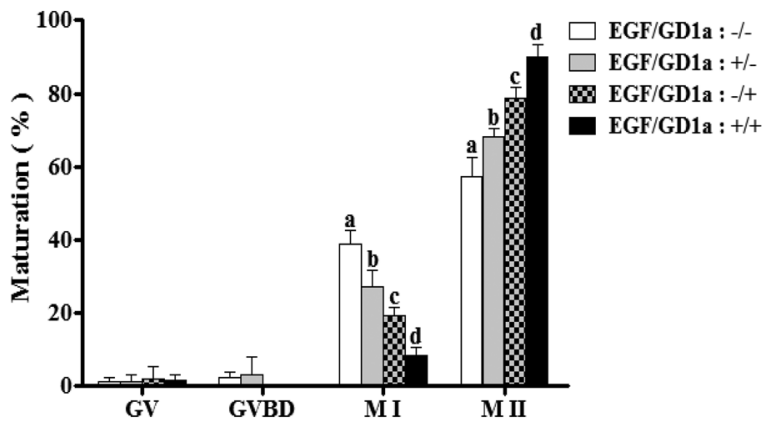

(C)

\begin{tabular}{|c|c|c|c|c|c|c|c|}
\hline \multirow{2}{*}{$\underset{\text { (h) }}{\text { Time }}$} & \multirow{2}{*}{ EGF } & \multirow{2}{*}{ GD1a } & \multirow{2}{*}{$\begin{array}{c}\text { No. of } \\
\text { oocytes } \\
\text { examined }\end{array}$} & \multicolumn{4}{|c|}{$\%$ oocytes (n) } \\
\hline & & & & GV & GVBD & M I & M II \\
\hline \multirow{4}{*}{22} & - & - & 140 & $25.0 \pm 0.0(35)^{\mathrm{a}}$ & $10.0 \pm 0.8(14)$ & $65.0 \pm 0.8(91)^{\mathrm{a}}$ & - \\
\hline & + & - & 136 & $40.4 \pm 2.1(55)^{b}$ & $11.1 \pm 0.9(15)$ & $48.5 \pm 1.7(66)^{b}$ & - \\
\hline & - & + & 138 & $33.2 \pm 3.7(46)^{c}$ & $10.1 \pm 4.2(14)$ & $56.6 \pm 2.7(78)^{c}$ & - \\
\hline & + & + & 142 & $41.6 \pm 1.5(59)^{b}$ & $13.4 \pm 5.1(19)$ & $45.0 \pm 4.4(64)^{b}$ & - \\
\hline \multirow{4}{*}{44} & - & - & 222 & $1.3 \pm 1.3(3)$ & $2.3 \pm 1.8(5)$ & $39.0 \pm 3.6(86)^{a}$ & $57.4 \pm 5.3(128)^{a}$ \\
\hline & + & - & 212 & $1.3 \pm 2.0$ & $3.2 \pm 4.9(5)$ & $27.2 \pm 4.6(60)^{b}$ & $68.3 \pm 2.3(144)^{b}$ \\
\hline & - & + & 194 & $2.0 \pm 3.5(3)$ & - & $19.4 \pm 2.3(39)^{c}$ & $78.6 \pm 3.0(152)^{c}$ \\
\hline & + & + & 195 & $1.7 \pm 1.6(4)$ & - & $8.4 \pm 2.1(17)^{d}$ & $89.9 \pm 3.6(174)^{d}$ \\
\hline
\end{tabular}

Fig. 3. Effects of EGF and/or GD1a treatment on meiotic maturation of porcine oocytes in IVM I ( $22 \mathrm{~h}$ ), and IVM II (44 h). Diagram of oocyte maturation at IVM I (22 h) (A), and IVM II (44 h) (B). (C) Summary of meiotic maturation after IVM I and IVM II. Nuclei were classified into GV, GVBD, M I, or M II stages. This experiment was replicated at three times. Data are expressed as the means \pm SD. Different superscript letters denote significant differences $(\mathrm{P}<0.05)$.

the untreated control group $(65.0 \pm 0.8 \%)$ than after treatment with EGF alone $(48.5 \pm 1.7 \%)$, GD1a alone $(56.6 \pm 2.7 \%)$ or EGF+GD1a $(45.0 \pm 4.4 \%)$. In contrast, the proportion of M II oocytes were significantly increased $(\mathrm{P}<0.05)$ in the EGF alone $(68.3 \pm 2.3 \%)$, GD1a alone $(78.6 \pm 3.0 \%)$, and EGF+GD1a treated $(89.9 \pm 3.6 \%)$ groups relative to the untreated control group $(57.4 \pm 5.3 \%)$ at the end of the maturation period $(44 \mathrm{~h})$. These result demonstrated that the proportion of meiotic maturation until IVM II increased in the group treated with EGF $(10 \mathrm{ng} / \mathrm{ml})$ and GD1a $(10 \mu \mathrm{M})$.

\section{Effects of EGF and/or GD1a supplementation on fertilization} parameters, developmental competence, and apoptotic patterns of blastocysts

To investigate the effects of exogenous GD1a treatment on blastocyst development and fertilization rate after in vitro fertilization (IVF), we examined fertilization parameters, developmental competence, and apoptotic patterns of porcine blastocysts.

As shown in Fig. 4B, the proportion of penetration in oocytes of the $\mathrm{EGF}+\mathrm{GD} 1$ a treated group $(89.1 \pm 2.3 \%)$ was significantly higher $(\mathrm{P}<0.05)$ than that of the EGF treated group $(80.8 \pm 0.9 \%)$, the GD1a treated group $(82.6 \pm 6.8 \%)$, and the control $(69.4 \pm 2.2 \%)$ group. In addition, the proportion of cells with normal pronuclear formation $(2 \mathrm{PN})$ was greater $(\mathrm{P}<0.05)$ in the $\mathrm{EGF}+\mathrm{GDla}$ treated group $(43.1 \pm 5.2 \%)$ than in the EGF treated group $(31.0 \pm 1.4 \%)$, the GD1a treated group (31.6 $\pm 3.0 \%)$, and the control group (26.4 $\pm 3.4 \%$ ) (Fig. 4A). Moreover, the percentage of polyspermic oocytes was significantly decreased $(\mathrm{P}<0.05)$ in the $\mathrm{EGF}+\mathrm{GD} 1 \mathrm{a}$ treated group $(41.5 \pm 1.5 \%)$ relative to the EGF treated group $(47.7 \pm 2.9 \%)$, the GDla treated group $(45.7 \pm 0.4 \%)$, and the control group (45.2 $\pm 0.4 \%$ ) (Fig. 4C).

We measured the rate of development to blastocyst formation in IVF-derived porcine embryos from matured oocytes grown in maturation medium supplemented with EGF and/or GD1a. Treatment with $\mathrm{EGF}+\mathrm{GD} 1$ a resulted in development rates that were faster $(47.5$ $\pm 5.0 \%)(\mathrm{P}<0.05)$ than those of the matured control $(25.5 \pm 2.4 \%)$, treatment with EGF alone $(33.0 \pm 1.4 \%)$, and treatment with GD1a alone (33.7 $\pm 2.1 \%$ ) (Fig. 5). Although no significant differences in cleavage were detected between groups under different maturation conditions, we confirmed that GD1a increases preimplantation developmental ability via stimulation of meiotic maturation of porcine oocytes.

Apoptosis was measured using the TUNEL assay (Fig. 6). The number of total nuclei was significantly higher $(\mathrm{P}<0.05)$ in blastocysts derived from EGF+GD1a treated embryos $(50.6 \pm 10.4)$ than in the control group (34.7 \pm 11.0$)$. In addition, the number of TUNELpositive nuclei was significantly lower $(\mathrm{P}<0.05)$ in blastocysts 
(A)

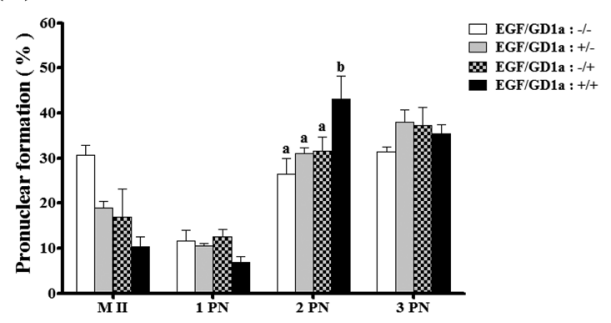

(B)

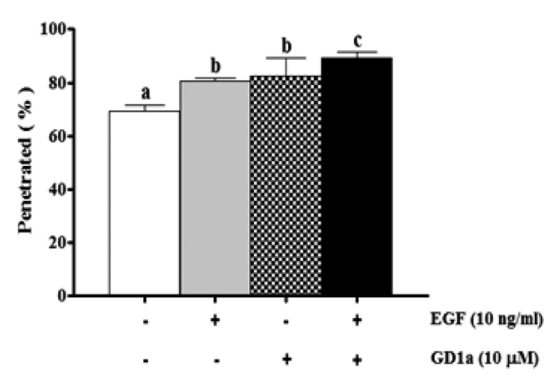

(C)

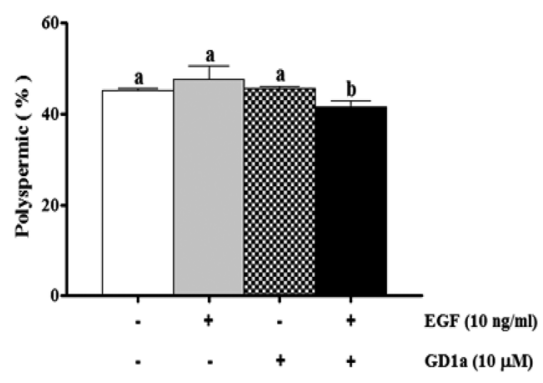

(D)

\begin{tabular}{|c|c|c|c|c|c|c|c|c|}
\hline \multirow{2}{*}{ EGF } & \multirow{2}{*}{ GD1a } & \multirow{2}{*}{$\begin{array}{c}\text { No. of } \\
\text { oocytes } \\
\text { examined }\end{array}$} & \multicolumn{4}{|c|}{$\%$ pronuclear formation (n) } & \multirow{2}{*}{$\begin{array}{c}\% \\
\text { oocytes } \\
\text { penetrated } \\
\text { (n) }\end{array}$} & \multirow{2}{*}{$\begin{array}{c}\% \\
\text { polyspermi } \\
\text { oocytes }(\mathrm{n})\end{array}$} \\
\hline & & & M II & $1 \mathrm{PN}$ & $2 \mathrm{PN}$ & $\geq 3 \mathrm{PN}$ & & \\
\hline - & - & 141 & $30.6 \pm 2.2(46)^{\mathrm{a}}$ & $11.6 \pm 2.5(16)^{2}$ & $26.4 \pm 3.4(36)^{\mathrm{a}}$ & $31.4 \pm 1.1(43)^{\mathrm{a}}$ & $69.4 \pm 2.2^{\mathrm{a}}$ & $45.2 \pm 0.4^{\mathrm{a}}$ \\
\hline+ & - & 140 & $19.0 \pm 1.4(24)^{b}$ & $10.6 \pm 0.5(18)^{2}$ & $31.0 \pm 1.4(45)^{2}$ & $38.0 \pm 2.8(53)^{b}$ & $80.8 \pm 0.9^{b}$ & $47.7 \pm 2.9^{2}$ \\
\hline - & + & 140 & $17.0 \pm 6.2(27)^{b}$ & $12.6 \pm 1.6(15)^{\mathrm{a}}$ & $31.6 \pm 3.0(44)^{\mathrm{a}}$ & $37.2 \pm 4.0(54)^{b}$ & $82.6 \pm 6.8^{b}$ & $45.7 \pm 0.4^{\mathrm{a}}$ \\
\hline+ & + & 138 & $10.4 \pm 2.1(15)^{\mathrm{c}}$ & $6.9 \pm 1.2(10)^{b}$ & $43.1 \pm 5.2(62)^{b}$ & $35.4 \pm 2.1(51)^{b}$ & $89.1 \pm 2.3^{\mathrm{c}}$ & $41.5 \pm 1.5^{b}$ \\
\hline
\end{tabular}

Fig. 4. Effects of EGF and/or GD1a treatment on oocyte fertilization variables during in vitro maturation. (A) Pronuclear formation, (B) penetrated oocytes, (C) polyspermic oocytes, (D) and summary of fertilization. This experiment was replicated at three times. Data are expressed as the means $\pm \mathrm{SD}$. Different superscript letters denote significant differences $(\mathrm{P}<0.05)$.

(A)

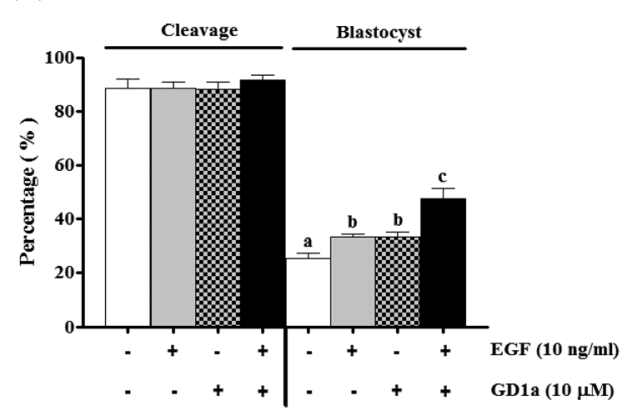

(B)

\begin{tabular}{ccccc}
\hline EGF & GDla & $\begin{array}{c}\text { No. of } \\
\text { embryos culture }\end{array}$ & $\begin{array}{c}\text { \% embryos cleaved } \\
(\mathrm{n})\end{array}$ & $\begin{array}{c}\% \text { blastocysts } \\
(\mathrm{n})\end{array}$ \\
\hline- & - & 177 & $88.7 \pm 6.5(157)$ & $25.5 \pm 2.4(44)^{\mathrm{a}}$ \\
\hline+ & - & 180 & $88.6 \pm 4.4(160)$ & $33.0 \pm 1.4(59)^{\mathrm{b}}$ \\
\hline- & + & 180 & $88.3 \pm 4.6(160)$ & $33.7 \pm 2.1(60)^{\mathrm{b}}$ \\
\hline+ & + & 184 & $91.6 \pm 4.8(168)$ & $47.5 \pm 5.0(85)^{\mathrm{c}}$ \\
\hline
\end{tabular}

Fig. 5. Effects of EGF and/or GD1a treatment on developmental competence of porcine oocytes in vitro. (A) Pattern of cleavage and blastocyst formation after IVF embryos. (B) Summary of developmental competence. This experiment was replicated at three times. Data are expressed as the means \pm SD. Different superscript letters denote significant differences $(\mathrm{P}<0.05)$. derived from EGF+GD1a treated embryos $(1.2 \pm 1.0)$ than in the control $(2.0 \pm 1.3)$. Moreover, we confirmed that the percentage of TUNEL-positive cells (apoptotic cells) gradually decreased in groups treated with GD1a alone, EGF alone, and EGF+GD1a. These results indicate that addition of GD1a to porcine oocytes yields dramatic improvements in oocyte quality as well as in the rates of blastocysts development. Taken together, the data suggests exogenous GD1a treatment positively affects oocyte maturation by increasing fertilization rate, increasing developmental competence, and decreasing apoptosis of blastocysts.

\section{Discussion}

In the present study, we first identified that the expression of ganglioside GD1a synthesizing enzyme ST3GAL2 only increased in cumulus cell oocyte complexes (COCs) during IVM progress. Moreover, we confirmed that addition of GD1a to IVM medium improved meiotic maturation, the fertilization parameters, and preimplantation development of porcine embryos.

According to recent studies, changes in ganglioside and ganglioside synthesizing enzyme expression patterns in blastocysts can have profound impacts on embryo development and competence [23, 24]. As shown in Fig. 1, we measured the expression of ganglioside GD1a synthesizing enzyme ST3GAL2 in COCs during IVM progression. Ganglioside GD1a is specifically formed by the addition of sialic acid to GM1a by ST3GAL2. Therefore, we estimated the expression of GD1a by measuring ST3GAL2 expression.

Gangliosides modulate various signal transduction molecules, 
(A)

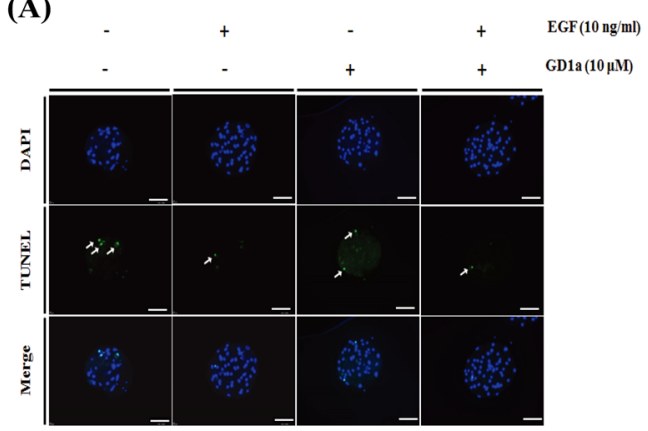

(B)

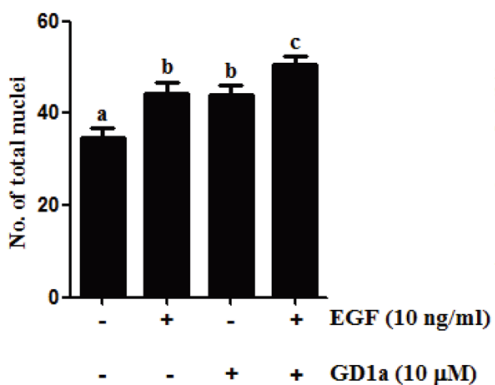

(C)

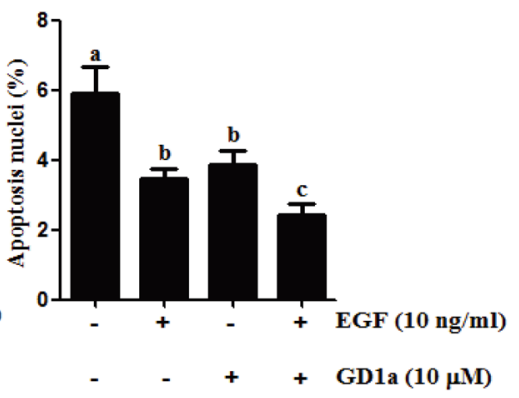

(D)

\begin{tabular}{|c|c|c|c|c|c|}
\hline \multirow{2}{*}{ EGF } & \multirow{2}{*}{ GD1 a } & \multirow{2}{*}{$\begin{array}{l}\text { No. of embryos } \\
\text { examined }\end{array}$} & \multicolumn{2}{|c|}{ No. of cells } & \multirow{2}{*}{ TUNEL-positive cells (\%) } \\
\hline & & & Total & TUNEL-positive & \\
\hline- & - & 32 & $34.7 \pm 11.0^{\mathrm{a}}$ & $2.0 \pm 1.3^{\mathrm{a}}$ & $5.9 \pm 4.2^{\mathrm{a}}$ \\
\hline+ & - & 30 & $44.2 \pm 13.5^{b}$ & $1.5 \pm 0.9^{b}$ & $3.4 \pm 1.7^{\mathrm{b}}$ \\
\hline- & + & 40 & $43.9 \pm 13.5^{b}$ & $1.6 \pm 1.1^{\mathrm{ab}}$ & $3.9 \pm 2.7^{\mathrm{b}}$ \\
\hline+ & + & 39 & $50.6 \pm 10.4^{\mathrm{c}}$ & $1.2 \pm 1.0^{\mathrm{b}}$ & $2.4 \pm 2.2^{c}$ \\
\hline
\end{tabular}

Fig. 6. Apoptosis scanning images of porcine blastocysts derived from EGF and/or GD1 a treated oocytes. (A) The chromatin content was determined by DAPI staining (total DNA, blue); fragmented DNA was detected by TUNEL assay (apoptotic nuclei, green). Scale bars $=100 \mu \mathrm{m}$. (B) Total cell number and (C) percent of apoptotic cells in porcine blastocyst-stage embryos after EGF and/or GD1a treatment. (D) Summary of developmental competence. This experiment was replicated at three times. Data are the means \pm SD. Different superscript letters denote significant differences $(P<0.05)$.

including PDGFR, EGFR, insulin receptor, and nerve growth factor, in both extracellular and intracellular molecular interactions [3]. GD1a was previously found to be expressed in interstitial cells, theca cells, and oocytes during ovarian maturation in mice [17]. Additionally, the inhibition of GD1a synthesis suppresses the differentiation of human mesenchymal stem cells into osteoblasts [15]. In addition, exogenous ganglioside GD1a enhances EGF receptor ligand binding, dimerization, and signaling activation [16]. Therefore, we speculated that ganglioside GDla was involved in development of COCs during IVM, through a mechanism similar to EGF-regulated EGFR signaling.

Consequently, we identified the effects of exogenous GD1a treatment on meiotic maturation of porcine oocytes. Exogenous GD1a at $20 \mu \mathrm{M}$ was previously found to induce phosphorylation of EGFR in normal human dermal fibroblast cells [16]; therefore, the present study was conducted to determine the optimum concentration of GDla in porcine oocytes by monitoring meiotic maturation to the metaphase II (M II) stage. A significantly higher proportion of oocytes reached M II in the $10 \mu \mathrm{M}$ GDla treated group than in the control group in our present study (Fig. 2). GD1a was previously shown to enhance EGF-induced EGFR phosphorylation, while the inhibition of ganglioside GD1a synthesis significantly suppressed the phosphorylation of EGFR $[15,16]$. In the present study, the effects of GD1a and/or EGF treatment on nuclear maturation during IVM periods of porcine oocytes were investigated. The proportion of GV arrested oocytes was significantly higher in the EGF alone, GD1a alone, and EGF+GD1a treatment groups than the untreated control group. Additionally, the proportion of M II stage oocytes increased gradually in the EGF alone, GD1a alone, and EGF+GD1a treatment groups relative to the untreated control group (Fig. 3). Taken together, these results suggest that EGF plays an important role in porcine oocyte maturation, and that GDla may affect EGF-mediated porcine oocyte activation. The proportion of M II stage oocytes is likely to have been enhanced by the interaction of EGF and GD1a. These findings suggest that addition of exogenous GD1a may help maintain EGF-induced activation of EGFR signaling.

Polyspermy is a common phenomenon in pigs, and polyspermic fertilization occurs more frequently than in other species under diverse experimental conditions [25]. Polyspermic fertilization has been a perennial problem impacting porcine IVF systems; therefore, this study was conducted to confirm potential oocyte deficiencies and improve embryo conditions after performing IVF [26]. We found that GD1a treatment during the IVM process enhanced oocyte maturation rate and there were more penetrated oocytes after IVF, but the number of polyspermic oocytes decreased (Fig. 4), and blastocyst formation rates increased after IVC (Fig. 5). Previous reports demonstrated that regulating oocyte maturation with dbcAMP treatment was associated with increased blastocyst formation rates as well as monospermic fertilization via in vitro culture of porcine embryos [27, 28]. Therefore, our findings indicate that GD1a treatment is essential for preserving the improvement in oocyte quality and monospermic fertilization achieved during the in vitro maturation process of porcine oocytes. Furthermore, the quality of maturated oocytes affects the developmental competence and viability of porcine embryos after IVF. 
Apoptosis has received increasing attention in the IVF research field because of its potential role in the cellular responses to stress, suboptimal developmental conditions, and early embryonic loss [29]. Overall, data suggests that the composition of a maturation medium has significant effects on apoptosis in blastocyst-stage embryos, and an optimal medium can lead to an overall decrease in susceptibility to embryo apoptosis. As expected, the number of apoptotic nuclei was dramatically lower in blastocysts of the EGF+GD1a treated group than in the untreated control. In addition, the total cell numbers were significantly higher in blastocysts treated with EGF+GD1a than in untreated controls (Fig. 6). Our results showed that GD1a promotes effective and high-quality blastocyst development. In future studies, we plan to investigate the effect of GDla treatment on EGFR-induced downstream signaling pathways during IVM of porcine oocytes.

In summary, the present study provides the first evidence associating exogenous GD1a treatment with the promotion of porcine oocyte meiotic maturation during IVM. Exogenous GD1a played a critical role in meiotic progression in porcine oocytes, which influenced fertilization status and subsequent preimplantation development. Furthermore, we found that the embryonic qualities and developmental potential, including structural integrity and apoptotic patterns, of porcine IVF embryos can be determined based on the maturation conditions in the presence or absence of GD1a and early embryo development processes in porcine. Our results will be beneficial to achieving a better understanding of the relationship between gangliosides and meiotic maturation during porcine in vitro maturation and early embryo development processes.

\section{Acknowledgments}

This work was supported by grants from the Next-Generation BioGreen 21 Program (PJ01117604) and the Basic Science Research Program (NRF-2015R1D1A1A01057103) through the Rural Development Administration, the Ministry of Education, and the KRIBB Research Initiative Program (KGM4251622), Republic of Korea.

\section{References}

1. Mirkin BL, Clark SH, Zhang C. Inhibition of human neuroblastoma cell proliferation and EGF receptor phosphorylation by gangliosides GM1, GM3, GD1A and GT1B. Cell Prolif 2002; 35: 105-115. [Medline] [CrossRef]

2. Kwak DH, Seo BB, Chang KT, Choo YK. Roles of gangliosides in mouse embryogenesis and embryonic stem cell differentiation. Exp Mol Med 2011; 43: 379-388. [Medline] [CrossRef]

3. Kim SM, Jung JU, Ryu JS, Jin JW, Yang HJ, Ko K, You HK, Jung KY, Choo YK. Effects of gangliosides on the differentiation of human mesenchymal stem cells into osteoblasts by modulating epidermal growth factor receptors. Biochem Biophys Res Commun 2008; 371: 866-871. [Medline] [CrossRef]

4. Xu Y, Tan LJ, Grachtchouk V, Voorhees JJ, Fisher GJ. Receptor-type protein-tyrosine phosphatase-kappa regulates epidermal growth factor receptor function. $J$ Biol Chem 2005; 280: 42694-42700. [Medline] [CrossRef]

5. Scaltriti M, Baselga J. The epidermal growth factor receptor pathway: a model for targeted therapy. Clin Cancer Res 2006; 12: 5268-5272. [Medline] [CrossRef]

6. Uhm SJ, Gupta MK, Yang JH, Chung HJ, Min TS, Lee HT. Epidermal growth factor can be used in lieu of follicle-stimulating hormone for nuclear maturation of porcine oocytes in vitro. Theriogenology 2010; 73: 1024-1036. [Medline] [CrossRef]

7. Illera MJ, Lorenzo PL, Illera JC, Petters RM. Developmental competence of immature pig oocytes under the influence of EGF, IGF-I, follicular fluid and gonadotropins during
IVM-IVF processes. Int J Dev Biol 1998; 42: 1169-1172. [Medline]

8. Singh B, Meng L, Rutledge JM, Armstrong DT. Effects of epidermal growth factor and follicle-stimulating hormone during in vitro maturation on cytoplasmic maturation of porcine oocytes. Mol Reprod Dev 1997; 46: 401-407. [Medline] [CrossRef]

9. Ben-Yosef D, Galiani D, Dekel N, Shalgi R. Rat oocytes induced to mature by epidermal growth factor are successfully fertilized. Mol Cell Endocrinol 1992; 88: 135-141. [Medline] [CrossRef]

10. De La Fuente R, O'Brien MJ, Eppig JJ. Epidermal growth factor enhances preimplantation developmental competence of maturing mouse oocytes. Hum Reprod 1999; 14: 3060-3068. [Medline] [CrossRef]

11. Goud PT, Goud AP, Qian C, Laverge H, Van der Elst J, De Sutter P, Dhont M. In-vitro maturation of human germinal vesicle stage oocytes: role of cumulus cells and epiderma growth factor in the culture medium. Hum Reprod 1998; 13: 1638-1644. [Medline] [CrossRef]

12. Lonergan P, Carolan C, Van Langendonckt A, Donnay I, Khatir H, Mermillod P. Role of epidermal growth factor in bovine oocyte maturation and preimplantation embryo development in vitro. Biol Reprod 1996; 54: 1420-1429. [Medline] [CrossRef]

13. Gall L, Boulesteix C, Ruffini S, Germain G. EGF-induced EGF-receptor and MAP kinase phosphorylation in goat cumulus cells during in vitro maturation. Mol Reprod Dev 2005; 71: 489-494. [Medline] [CrossRef]

14. Gall L, Chene N, Dahirel M, Ruffini S, Boulesteix C. Expression of epidermal growth factor receptor in the goat cumulus-oocyte complex. Mol Reprod Dev 2004; 67: 439-445. [Medline] [CrossRef]

15. Yang HJ, Jung KY, Kwak DH, Lee SH, Ryu JS, Kim JS, Chang KT, Lee JW, Choo YK. Inhibition of ganglioside GDla synthesis suppresses the differentiation of human mesenchymal stem cells into osteoblasts. Dev Growth Differ 2011; 53: 323-332. [Medline] [CrossRef]

16. Liu Y, Li R, Ladisch S. Exogenous ganglioside GDla enhances epidermal growth factor receptor binding and dimerization. J Biol Chem 2004; 279: 36481-36489. [Medline] [CrossRef]

17. Choo YK, Chiba K, Tai T, Ogiso M, Hoshi M. Differential distribution of gangliosides in adult rat ovary during the oestrous cycle. Glycobiology 1995; 5: 299-309. [Medline] [CrossRef]

18. Funahashi H, Cantley TC, Stumpf TT, Terlouw SL, Day BN. In vitro development of in vitro-matured porcine oocytes following chemical activation or in vitro fertilization. Biol Reprod 1994; 50: 1072-1077. [Medline] [CrossRef]

19. Petters RM, Wells KD. Culture of pig embryos. J Reprod Fertil Suppl 1993; 48: 61-73. [Medline]

20. Abeydeera LR, Day BN. Fertilization and subsequent development in vitro of pig oocytes inseminated in a modified tris-buffered medium with frozen-thawed ejaculated spermatozoa. Biol Reprod 1997; 57: 729-734. [Medline] [CrossRef]

21. Nomura M, Shimbo T, Miyamoto Y, Fukuzawa M, Kaneda Y. 13-Cis retinoic acid can enhance the antitumor activity of non-replicating Sendai virus particle against neuroblastoma. Cancer Sci 2013; 104: 238-244. [Medline] [CrossRef]

22. Wang L, Wang Y, Sato T, Yamagata S, Yamagata T. Ganglioside GD1a suppresse TNFalpha expression via Pkn1 at the transcriptional level in mouse osteosarcoma-derived FBJ cells. Biochem Biophys Res Commun 2008; 371: 230-235. [Medline] [CrossRef]

23. Ju EJ, Kwak DH, Lee DH, Kim SM, Kim JS, Kim SM, Choi HG, Jung KY, Lee SU, Do SI, Park YI, Choo YK. Pathophysiological implication of ganglioside GM3 in early mouse embryonic development through apoptosis. Arch Pharm Res 2005; 28: 1057-1064. [Medline] [CrossRef]

24. Kim BH, Jung JU, Ko K, Kim WS, Kim SM, Ryu JS, Jin JW, Yang HJ, Kim JS, Kwon HC, Nam SY, Kwak DH, Park YI, Koo DB, Choo YK. Expression of ganglioside GT1b in mouse embryos at different developmental stages after cryopreservation. Arch Pharm Res 2008; 31: 88-95. [Medline] [CrossRef]

25. Suzuki H, Saito Y, Kagawa N, Yang X. In vitro fertilization and polyspermy in the pig: factors affecting fertilization rates and cytoskeletal reorganization of the oocyte. Microsc Res Tech 2003; 61: 327-334. [Medline] [CrossRef]

26. Grupen CG. The evolution of porcine embryo in vitro production. Theriogenology 2014 81: 24-37. [Medline] [CrossRef]

27. Somfai T, Kikuchi K, Onishi A, Iwamoto M, Fuchimoto D, Papp AB, Sato E, Nagai T. Meiotic arrest maintained by cAMP during the initiation of maturation enhances meiotic potential and developmental competence and reduces polyspermy of IVM/IVF porcine oocytes. Zygote 2003; 11: 199-206. [Medline] [CrossRef]

28. Kim JS, Cho YS, Song BS, Wee G, Park JS, Choo YK, Yu K, Lee KK, Han YM, Koo DB. Exogenous dibutyryl cAMP affects meiotic maturation via protein kinase A activation; it stimulates further embryonic development including blastocyst quality in pigs. Theriogenology 2008; 69: 290-301. [Medline] [CrossRef]

29. Betts DH, King WA. Genetic regulation of embryo death and senescence. Theriogenology 2001; 55: 171-191. [Medline] [CrossRef] 